\title{
Food Safety Problems in China: Based on the Illegally Waste Cooking Oil
}

\section{Chen Chuangbin, Nie Haisong*}

Department of International Environment and Agricultural Science, Tokyo University of Agriculture and Technology, 183-8509, Fuchu, Tokyo, Japan.

*Corresponding author's e-mail: nie-hs@cc.tuat.ac.jp

How to Cite: Chuangbin, C., and Haisong, N. (2019). Food Safety Problems in China: Based on the Illegally Waste Cooking Oil. Int. J. Agr. Syst. 7(2): 138-147

\begin{abstract}
The illegal oil (coming from the waste cooking oil and animals' fat, etc.) is being processed as daily edible oil by a series of processing programs in China. It contains enormous toxic carcinogenic substances such as aflatoxin, dioxins, and polychlorinated biphenyls (PCBs), etc. In China, 22 million tons of cooking oil is approximately consumed each year, however, 2-3 million tons (account for 10\%) of the illegal oil is circulated back to the daily market finally. This research aims to analyze four parts among the illegal oil. It combines the Chinese food safety legal loophole with the treatments of other developed countries to solve China's illegal oil problem. What's more, carrying out a field survey is conducted to understand the source of the illegal oil and have a clear understanding of consumers' usage. Next, the main reason for the spread of the illegal oil which is from the street stalls and restaurants is revealed. The new technique is also used to transform the illegal oil into biodiesel fuel $(B D F)$, however, the material (the illegal oil) cannot be easily obtained due to many barriers and challenges in China. Based on the field survey results, setting up a specific feedback mechanism for restaurants/hotels and the other policy implications are proposed to China's governments for solving the illegal oil issue in China.
\end{abstract}

Copyright $\odot 2019$ IJAS. All rights reserved.

\section{Keywords:}

the Illegal Oil; Food Safety; BDF; Cooking Oil; Street Stalls.

\section{Introduction}

The illegally recycled waste cooking oil (the illegal oil) is being processed as daily edible cooking oil over the last decade in China. The processes of producing the illegal oil are complicated which include heating, sedimentation, and separation, etc. A recent government report (The Supreme People's Court et al., 2012) shows that the illegal oil is defined into three types, the traditional type (coming from kitchen, restaurants and hotels, etc.), the evolving type (coming from the waste cooking oil such as fried food, etc.), the new type (coming from using waste meat and animals' internal organs, etc.). Since 2010, the illegal oil has become as a public issue in China after being published in China Youth on Line ("Enclosing illegal oil", 2010). Human are provoked by the impact of the illegal oil and could not also avoid focusing on the food safety problems in China. 
On the contrary, the Chinese government is strictly taking effective measures to cut off the supply and demand of the illegal oil, however, driven by the huge profit from the utilization of illegal oil, many criminals are being caught in the street stalls and restaurants persistently. It is unimaginable how dangerous it is that the illegal oil is still being circulated in Chinese market. It has been widely acknowledged that the waste cooking oil might be contaminated during cooking over a long time. Many seasonings and food particles are mixed into the waste cooking oil, which could accelerate the deterioration of the waste cooking oil.

Additionally, it contains a variety of harmful carcinogenic substances, such as aflatoxin, dioxin, and PCBs after being processed from the overused waste cooking oil since a complicated fatty acid composition is not refined completely (Tang et al., 2014). Furthermore, the initial stages of danger from consuming the illegal oil would be dizziness, headache, and diarrhoea which would make people lack nutrition and accelerate aging. However, for a long term, it would destroy the digestive tract mucosa, and organs would be damaged. Although relevant measures are taken after it happened in China, the handling capacity is not enough and there are no standardized criteria. The dangerous illegal oil not only can affect the health of Chinese citizens, but also it will have a negative effect on its international relationship, especially the countries that import edible oil from China.

This research is combining the Chinese food safety legal loophole with other developed countries' treatments to solve China's illegal oil issue. It mainly compares literature such as preliminary research, thesis, agency newspaper articles which are obtained in China. Meanwhile, carrying out a field survey is to understand the source of the illegal oil and have a clear realization on the usage of consumers. Moreover, the new technique is used by transforming the illegal oil into Bio Diesel Fuel (BDF), however, the row material of illegal oil faces many barriers and challenges in China. The objectives of this research would answer these following questions: 1 ). Where does the illegal oil come from? 2). Although there is a law/regulation, why is the illegal oil still breaking out in China? 3). Why does the illegal oil mainly spread on street stalls and restaurants? 4). What countermeasures are available to the Chinese government? After solving these problems, setting up a specific feedback mechanism for restaurants/hotels and the other policy implications are proposed to China's governments for solving the illegal oil issue in China.

\section{Materials and Methods}

After 2002, there are massive papers regarding how to solve this illegal oil issue in China's database (CNKI). With China's rapidly developing economy and its progressing society, people pay more and more attention to the food safety problems. Therefore, many researchers have proposed some countermeasures which focus on how to solve the illegal oil problem in China. Among all the propositions, it mainly divides into three parts: the improvement of China's food safety law and administration; the development of new technique; and the field survey among consumers.

\subsection{Field of Law and Administration}

Nowadays, food safety problems in China cannot be successfully resolved by the single market mechanism or by the government alone. The government should work as the leader, when market and society forces combine to better solve China's food safety 
problem (Qin\&Wang,2008; Li,2010). The reward reporting system for the whistleblowers should be set up, and environmental protection and resource recycling awareness education should also be strengthened immediately (Wang, 2012). The food safety regulations are inadequate, and the crackdown of food safety crime is not enough. Additionally, it is difficult to penalize people in practice, because it is so hard to calculate the number of fines involved in food safety crimes (Liu, 2012; Li, 2014). The Chinese government must set up a special food safety regulation to unify supervision among all the food safety problems in China and divide the responsibility for each food safety crime (Gao et al., 2013). Moreover, each house should be equipped with a container to collect the waste cooking oil. At the same time, the government can lower the price of edible oil to balance the market $(X u, 2017)$. The Internet is the platform used to expose the illegal oil incident (Guan, 2018).

\subsection{New Technique Field}

In 2002, it was the first time that the illegal oil could be transformed into biodiesel fuel (BDF) (Peng, 2002). However, for the pursuit of individual benefits, many restaurant owners sold the illegal oil to the collecting merchants. For this reason, the progress of producing BDF is becoming lower due to the lack of raw materials. Ten years later, the illegal oil has successfully been transformed into BDF by developing hightechnological, energy-saving and economical biofuels, however, the outcome ratio is also lower than the other advanced countries. Although some technological breakthroughs have been made, the practical application has not been able to reach the desired level. In the current situation, the government need to protect the normal source of the waste cooking oil to ensure the continuous transformation of the illegal oil into BDF (Feng, 2017). What's more, other innovative technologies have also been developed to produce soap, detergent, and phosphorus-free laundry detergent (Liang et al., 2005). Besides, the illegal oil can also be transformed to industrial automotive lubricants (Tian, 2013), a new type of plasticizer (Luo et al., 2013).

\subsection{Field of the Market Survey}

A questionnaire survey (185copies) among citizens is carried out in Wuxi City, China to know the basic situation of the illegal oil in the perspective of consumers (Mei et al., 2013). A field investigation (463 copies) is also conducted in Beijing where there are more unmarried women in the survey sample. Additionally, the average personal monthly income (4880yuan) is extremely low (Shi, 2013). Another field investigation ( 512 copies) is carried out in rural areas, where the people have low education level. The factors, which could influence the risk of food safety, should be taken into consideration (Guo, 2014). Based on unbalanced market information, the reasons why the illegal oil occurs in the catering consumption are analysed and discussed (Zhao, 2016; Chao, 2017).

Although there are many previous papers on how to solve the illegal oil in China, most of them only focused on improving the law and the development of modern technology. Even though technology has been utilized in the present, China's illegal oil problem has not been fundamentally solved. At the same time, there are few social science articles on the management of the illegal oil. What's more, other surveys are also conducted, but these questionnaires mostly consider on overall food safety and there is no specific research regarding the illegal oil. 
The primary method of this paper is to summarize the previous papers to know the thoughts of people who are usually involved in the illegal oil problem. What's more, a field interview is carried out in 2017 in Guangzhou City and Haikou City, China. As known to all, Guangzhou is the largest city in southern China, and Haikou City is the capital of Hainan Island which has China's major strategy for developing it a green island and harmonious island. In this paper, the questionnaire not only consider about food safety, but also it focuses on the problem of illegal oil. Meanwhile, subjects of this survey include consumers, street stall owners, and food safety inspectors. The advanced solving methods among other countries is another objective Furthermore, relevant food safety papers from other countries are read merely. Specifically, a field interview is carried out on the Japanese restaurant (Izagaya) and Japanese eating customs are observed. At last, why BDF has low productivity in China is analysed, and the situations of producing BDF between China and other countries are compared.

\section{Results and Discussion}

According to the previous studies and the field survey, results would be discussed into four aspects to analyse China's illegal oil problem in the following.

\subsection{Economic Interests and China's Low Food Safety Level}

Although the government has introduced relative policies to crack down the illegal oil problem, it has not been solved yet. Through the summary of the previous studies and the investigation of the causes of the illegal oil issue in recent years, the reasons why the illegal oil problem have not been solved would be known in the following paragraphs.

\subsubsection{Economic Interests behind Illegal Oil Production and Distribution}

Criminal suspects who sell the illegal oil would earn a substantial number of benefits from collecting, processing, marketing etc. The waste cooking oil is entrusted to the environmental supervision department originally, and restaurants/hotels must pay fees to them. However, if it is sold to criminal suspects, a lot of benefits would be earned. In this way, criminal suspects could easily collect a lot of waste cooking oil from restaurants or hotels. Additionally, it has the greatest benefit from processing and selling. The cost of waste cooking oil is about 1,000 yuan per ton, and 0.8 tons of the illegal oil could be extracted from a ton of waste cooking oil. The cost of processing is 300 yuan, but the edible oil price is 6000 yuan per ton in the market (Lu,2013). This overwhelming interest rate has been the main cause of the crime of collecting the waste cooking oil.

\subsubsection{Difficulties of China's Law Facing the Illegal Oil}

In China, there is a phenomenon that although there is the law, people rely on power or money to deal with the criminal incidents instead of following the law. Therefore, the incidents of illegal oil are increasing rapidly in last decades. The amendment of law is not implemented immediately. It is also pointed out that both the judiciary and the government departments are not functioning normally. In fact, in the production and distribution network of the illegal oil, food safety, business administration, safety supervision, quality supervision and other departments have the responsibility for it. Conversely, the responsibility is unspecified to this issue which has been mentioned in China's food safety law (beginning in October 2015), but it would take some time to solve such an issue fully. For example, in August 2014, two investigators (Zhang, 2014) 
were investigating whether there was illegal oil in a company named "Kangrui", but both of them worked irresponsibly and got bribery from the company, so a severe incident has happened. After the trial of the People's Court, both of them were sentenced to one year in prison for dereliction of duty. In this case, Chinese people have a profound distrust of the overall food safety surveillance and management system.

The illegal oil is a unique issue which is spread all over the China. It is also one of the food safety problems in China, without having a special law until October 2015. The illegal oil crime appears and is diversified, but it is unspecified which department should undertake the ultimate responsibility. The crime is a case concerning the food safety, but there are no regulations specializing in the illegal oil. Therefore, it should be proposed by the creation of the law on the illegal oil so that the same result could be obtained according no matter who oversaw the incident. There are two policy implications listed in the following.

This mechanism could implement a cash-reward model where units and individuals who disclose illegal acts are rewarded. At the same time, the government could praise the restaurant and hotel in public. Meanwhile, the waste recycling fees of restaurants and hotels would be abolished, so that the illegal oil dealers would be inclined to produce BDF to avoid the production of illegal oil from restaurants and manufacturers. If people are involved in the trafficking of the illegal oil, a certain penalty should be strengthened. The punishment should be distinguished with the other general food safety punishment, in order to alert other people. According to the survey, the criminal chains are especially consolidated. The government could make use of the undercover officers to investigate the criminal chains.

\subsection{Economic Interests and China's Low Food Safety Level}

Through the survey among consumers, the owners of the street stall, food safety inspectors, people with various occupations have different opinions or solving measures of the illegal oil. Consumers do not pay attention to the problem of the illegal oil because they only want to save much money by eating in the street stalls. Also, the owners of the street stall want to reduce the cost of materials for higher income. On the other hand, food safety inspectors choose a different approach to deal with the illegal oil problem, because of the bribe they receive from the street stalls.

\subsubsection{The Situations and Problems of Using Illegal Oil in Street Stalls}

From the field interview, it could be affirmed that most of the street stall owners are migrant workers and local habitants. They lack the skills or knowledge which should be needed to the local companies. It has been widely acknowledged that the street stalls have no business license which selling food and drink on the street is illegally. In this case, they must accept the consequences of not having a national health insurance and the possibility of being caught by the police. For migrant people who leave their hometown and work in other cities, the salary which they earn from the factory is not enough for their daily outcome, they should work hard to afford their children's tuition fees and their parents' daily expenses. At the same time, they should pay much money for renting houses in big cities and their daily expenses. These are the reasons why so many migrant workers eventually leave from factories to engage in street stalls illegally. For local habitants, who are familiar with the local city could smoothly control the place, where they would set up their stall and use illegal oil, without being easily caught by food safety inspectors. Although they understand that these behaviours do 
harm consumers' health, they think it is used by a little illegal oil which could not cause illness immediately. These consumers buy it once, so that they do not worry whether it is illegal oil or edible oil. Driven by interest with money, they use illegal oil mixed with edible oil in their stalls.

\subsubsection{The Situations and Problems of Consumers Eating at Street Stalls and Restaurants}

Most consumers who usually eat at street stalls are low-income workers and students. However, people who have considered safety never eat at street stalls, because they know that in street stalls, the food is not safe and fresh. After listening to students why they want to eat at street stalls, they say that they hope to maintain the relationship with their friends well, so they use street stalls as a place of communication and wanted to refresh themselves better after their heavy study. Furthermore, they say that they are not confident about their school canteen concerning the use of the illegal oil. In China, the school canteens are usually managed by signing a contract with other business companies. Meanwhile, the students hardly believe whether their school canteen uses edible oil or not because the canteen also want to cut down their expenses and gain more money from the original materials. It should be emphasized that food in the street stall is cheaper than in the school canteen.

\subsubsection{Different Inspecting Methods of Food Safety Inspectors}

The interview is carried out among food safety inspectors. Although there is a common food safety legislation in China, different cities adopt different inspecting methods. In the city where economic development is slow, it seems that the illegal oil problem is severely solved. However, in the city where economy is progressing, it seems that dealing with the illegal oil issue is loose due to various causes (gangsters, personal connections, bribery, etc.). Besides, different attitudes are held depending on the years of employment of food sanitation inspectors. The shorter years of employers are stricter to control the illegal oil incident which they inspect. Experienced employers deal with the illegal oil incident better.

Respondents from the Field Survey: According to the investigation and analysis of Guangzhou City and Haikou City, most respondents have a low income. Among them, a large number of people are willing to save money, so they don't care whether the food is safe or not. However, some of the respondents (college students) are mainly motivated by having a place to communicate with their friends. For owners of the street stall, they just accept low level of education and are forced to leave from their birthplace and work in other cities in order to avoid the penalty of the "One-child policy". At the same time, the lack of technical ability makes them impossible to earn more money by working in the enterprise. For the food inspectors, they also make use of the loopholes in the law and take their own interpersonal connections to inspect the illegal oil problem. There are three policy implications listed in the following.

Education is necessary to be practiced among students with food safety knowledge. School should instruct them to refuse illegal street stalls when they are not sure whether the food is safe or not. In this way, it would decrease the number of illegal street stalls, so the aim of this movement is to reduce the flow of the illegal oil. Positively popularizing food safety knowledge in the community is the way to increase awareness of food safety problems and self-protection ability. 
According to the field survey, most of the stall owners are the migrant people who lack the basic insurance. To promote the employment of migrant people, the government could offer opportunities of technical ability training.

The government should standardize the responsibilities and obligations of food safety inspectors. It could prevent them from judging differently on the crime of illegal oil due to their personal interests. Everything should be done in accordance to the laws and regulations. At the same time, corresponding punishment measures shall be enacted.

\subsection{Advanced Methods in Japan in Handling the Problem of Illegal Oil}

Japan is a highly developed country in Asia and culture is very similar with China. It is worth learning the Japanese advanced experiences and solving methods which can be adopted to solve China's illegal oil problem. After Japan's economic bubble, Japan had happened a comparable situation with China's illegal oil issue, however, it was immediately solved by Japanese government. In this part, the relevant food safety laws in Japan are read and field investigation is carried out in order to analyse why Japan is able to handle the illegal oil problem perfectly.

\subsubsection{The Severe Disposal Laws}

In the 1970s, Japan had formulated the law about the disposal and cleaning of waste cooking oil in enterprises. The law is applicable for the disposal of waste cooking oil into garbage, and it has stipulated that some items such as handling, and processing are also specified. In this law, food and beverage companies are prohibited to use the oil, so the waste cooking oil is directly poured away into drains, and it should be put into the specified containers which are in the care of the licensed transportation and processing enterprises. Therefore, contracts must be signed between the government and these professional companies. In the process of handling, the transportation enterprises should record a detailed investigation, and affirm whether the transportation to the processing enterprise is safe and done immediately. It is also stipulated that food and beverage companies could not change the disposal enterprises at will, and they could not sell the waste oil to other disposal enterprises. These enterprises should strictly deal with the waste oil according to the commission. At the same time, the castor oil is added immediately after collecting the waste oil then, it would be insignificant to heat and extract the waste cooking oil into edible oil. Therefore, it is significantly difficult to produce edible oil from the waste cooking oil in Japan.

\subsubsection{Handling Methods in Japanese Families}

It could be said that it is a characteristic of Japanese who have the habit of eating raw food. For deep-fried food such as tempura, vegetable oil is often used, but in Japan, they do not pour waste cooking oil into drains. Japanese families absorb it with kitchen paper, and then dispose as flammable garbage, or bring it to an oil collecting station established by the collectors. Even the oil that remained at the bottom of the pot is often wiped off with kitchen paper and throw away. In addition, many sewage pipes in Japan adopt $P$ shape and S shape, because the sewer pipe is bent, and oil could flow into the upper layer (oil is lighter than water). Incidentally, such a sewer pipe that always saves water in a bent portion design is called a siphon type trap and has a role of preventing intrusion of odor, insects, rats, etc. 


\subsubsection{Situation of BDF Production in Japan}

In Japan, the government recommend the production of BDF by subsidies and tax revenue. One of the aims is to eradicate the production of the illegal oil by generating profits with regenerated biodiesel fuel. By issuing subsidies to BDF producers by law, the waste cooking oil could be recycled at a higher price than the recycled price of illegal processing enterprises. The government collect the waste cooking oil from a food and beverage company at a low price. After refining as BDF, it is sold to the government at a higher price. As profits are sold to the government, people do not have to be bothered by selling the waste cooking oil to other individuals or illegal companies. At the same time, there is a stable market supply in Japan by using BDF generated from the waste cooking oil in preference to oil companies. It is used for government cars, garbage collection vehicles and community buses in some areas. Even in general, the price of BDF is lower than that of ordinary oil, and cars using $100 \% \mathrm{BDF}$ are exempted from the gasoline tax.

There is a problem that BDF companies had difficulty purchasing the waste cooking oil at a lower price than illegal oil contractors because of the economic efficiency of the crime. The illegal oil recovery mechanism would be improved immediately, and the GPS system should be introduced to trace collection vehicles to clearly know the transport situation. What's more, hygiene standards should be raised, and every restaurant or hotel should have their own trash bin. Regular collection and management of information flow are carried out.

\subsection{Advanced Handling Methods among Other Developed Countries}

Not only Japan has the advanced technology and the experience of solving waste cooking oil problem, but also other developed countries have more experience and innovative processing means. With these, there is going to be more choices to solve China's illegal oil problem.

\subsubsection{Set up Illegal Oil Recycling Trash Cans in Every Community}

In Germany, the illegal oil problem broke out in the 1970s. After that, each household should have a trash bin specified for waste oil, where the source and the usage of the oil is strictly recorded, so that the waste oil could be tracked and oversee the entire process. What's more, it is the same to the United States that trash cans should be installed in each community and the waste cooking oil is collected periodically. However, in the United States, many pulverized machines are set up in restaurants and private kitchens. These machines could cut and crush meat and vegetables which do not contain a lot of oil.

\subsubsection{Government Involved in Illegal Oil Recycling Management}

Italia has a regulation that restaurants are prohibited to collect the waste cooking from kitchen sinks. It must be handed over to collectors who has a business license issued by the Ministry of Environment, and a high penalty would be incurred if they disobeyed the regulation. In the United States, before you apply for a restaurant, you must prove that you will cooperate with the recycling enterprise and submit the receipt and relevant information of the enterprise to the government on a regular basis. In Canada, company owners would also be fined heavily if they are found to have violated sewer rules. The waste cooking oil in the restaurant is also recycled by the designated recycling company, and the government-related technical department checks the operation of the waste disposal equipment every week. 
There is much illegal oil in China as the alternative fuel, but advanced technology is required to adopt the illegal oil as $\mathrm{BDF}$, however poor-quality oil fails to be converted as fuel. The Chinese government could develop innovative technology or introduce other advanced countries' technologies like the Netherlands for the rapid conversion. Compared with the bioethanol business, there are fewer policies to support BDF production. The main force of China's BDF industry is private enterprises. The government would support the key company in each province and make them monopolise the market of waste cooking oil.

\section{Conclusion}

There are three main sectors which influence the illegal oil issue happened in China. They are 1). The China's food safety law in illegal oil issue, 2). The behaviors from the consumers, street stalls and food safety inspectors, 3). Challenges of recycling as BDF in China. It is necessary to regulate these three main sectors to help solve the illegal oil issue in China and even the other food safety problems. Seven policy implications that can help solve the illegal oil issue more successfully are: 1). Set up a feedback mechanism for restaurants and hotels, 2). Severe punishment for the criminal chain of the illegal oil, 3). Enhance basic food safety education, 4). Improve the insurance and increase corresponding technical training, 5). Regulate normative measures for food safety inspectors, 6). Ensure raw materials of the illegal oil, 7). Improve the transfer technology of the illegal oil.

\section{Acknowledgements}

Nothing can be completed without the cooperation of the institution and related organizations, the food safety inspectors, as well as the owners of street stalls and kind consumers eating at street stalls. It is a complicated process to finish this paper by collecting and organizing information under the help of laboratory members.

\section{References}

Chao, M. L. (2017). Study on rural consumer's food safety and consumption decisionmaking behaviour in the perspective of information asymmetry. Jiangnan University, China.

Enclosing illegal oil. (2010, March). China Youth on Line newsletter. Retrieved March 26, 2019, from http://zqb.cyol.com/content/2010-03/17/content_3138166.htm

Feng, W. W. (2017). Turning waste into precious "the illegal oil" for green utilization. Journal of Energy Conservation and Environmental Protection, (12):40-42.

Gao, Q. S., Lei, Q. C., \& He, H. (2013). Research progress and comments on the treatment of "the illegal oil". Journal of Ecological Economy, (01):67-70.

Guan, G. (2018, Jan 15). Crack down the illegal oil on Internet - the duty of everyone. China Art Daily, p. 02. Retrieved March 29, 2019, from http://www.cflac.org.cn/zgysb/dz/ysb/history/20180115/index.htm?page=/p age_2/201801/t20180114_392786.htm\&pagenum $=2$

Guo, S. H. (2013). Research on consumer's behaviour about the food safety evaluation in daily family. Jilin University, China.

Li, S. N. (2014). Study on the difficult problem of producing and selling poisonous and harmful food, Central China Normal University, China. 
Li, Y. L. (2010). Discussion on waste recovery management of catering industry -- a case study of Wuhan City. Journal of Wuhan Institute of Technology,29(04):100102.

Liang, F. H., Yin, P. H., Zhao, L., \& Wang, Y. (2005). Study on the production of phosphate-free detergent from the illegal oil. Journal of Guangdong Chemical, (09):10-13.

Liu, H. R. (2012). Research on criminal law protection of food safety in China, Lanzhou University, China.

Lu, P. (2013). A study on the management and outlet of the illegal oil -taking case of 9.13 as an example. Nanjing University of Technology, China.

Luo, M. H., Jin, X., Lei, H., \& Fang, Q. H. (2013). Effects of the illegal oil on the properties of natural rubber. Journal of Rubber Technology,11(05):18-20.

Mei, J. X., Zhu, J. W., \& Xu, J. (2013). Current situation of the illegal oil and its countermeasures based on Wuxi City as an example. Technology Horizon, (04):103+171.

Peng, L. (2002). Beihua University wants to transform "the illegal oil" into biofuel. Research on Renewable Resources, (03):25.

Qin, L., \& Wang, Q. S. (2008). Theory of public governance: A new perspective of food safety management. Journal of Changchun Institute of Engineering (Social Science edition), (02):34-36.

Shi, W. Q.; \& Zeng, Y. C. (2013). Research on consumers' search behaviour for food safety information -- based on a survey of Beijing consumers. Agricultural Technology and Economy, (04):43-52.

Tang, H. M., Hu, X. J., \& Yang, A. M. (2014). Analysis of factors affecting food safety. Chinese food and nutrition, (08):14 -16.

The Supreme People's Court, The Supreme People's Procuratorate, \&The Central People's Government of the People's Republic of China. (2012). Notice on severely punishing criminal activities of illegal oil in accordance with the law. Retrieved from http://www. hljcourt.gov.cn/lawdb/show.php?fid=147056

Tian, G. (2013). The illegal oil turns waste into treasure to help green drilling. Journal of Gas Industry,33(05):91.

Wang, B. B. (2012). Cause analysis of "the illegal oil" incident and legal Countermeasures, Shandong University, China.

Xu, Z. D. (2017). Study on the management of the illegal oil -- based on people's livelihood issues. Journal of Chinese Market, (11):241-242.

Zhang, X. (2014, August 15). Two food safety officials in the illegal oil case have been sentenced to one year for malfeasance. People's Daily Online. Retrieved March 29, 2019, from http://js.people.com.cn/n/2014 /0815/c360305-22004551.html

Zhao, C. H. (2016). Causes of "the illegal oil incident" from the perspective of market information asymmetry. Chinese Food and Nutrition,22(07):10-13. 